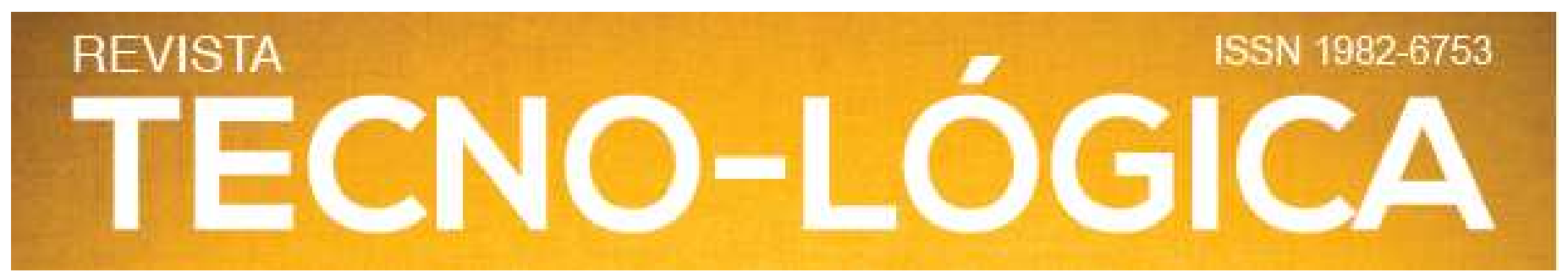

\title{
COSMETIC PRODUCTS FOR CHILDREN AND ADULTS - DETERMINATION OF As, Ni, Pb AND Zn CONTENTS
}

Alessandra Mocellin Zapp Popowiczk ${ }^{1}$, Larissa Macedo dos Santos-Tonial ${ }^{\text {* }}$

${ }^{1}$ Departamento Acadêmico de Química, Universidade Tecnológica Federal do Paraná, Via do Conhecimento, km 1, Bairro Fraron, Pato Branco, PR, Brasil.

*E-mail: larissasantos@utfpr.edu.br

Recebido em: 19/08/2020 Aceito em:21/12/2020 DOI: 10.17058/tecnolog.v25i1.15792

\begin{abstract}
The objective of this work was to determine the concentration of potentially toxic elements in different cosmetic products, using simple and accessible digestion methodologies, and spectroscopic techniques. A total of twelve products were selected, purchased and analyzed, which include blush (BL), eye shadow (SH), face powder (PO) and powdered paint for children (PP). The samples were dried (at $100^{\circ} \mathrm{C}$ ), crushed and homogenized. Two methodologies were used for digestion. The contents of Ni, Pb and $\mathrm{Zn}$ were quantified by atomic absorption spectrometry flame (FAAS), and the contents of As by atomic absorption spectrometry with electrothermal atomization in a graphite oven (GFAAS). In general, the samples showed contents below the detection limit (LOD) for Ni, Pb, As and Zn. However, some PP samples showed Zn contents between $2 \pm 1$ and $442 \pm 32 \mathrm{mg} \mathrm{L}-1$. This result is probably due to the use of some natural or inorganic pigments, and suggests the following actions: (1) regular monitoring of potentially toxic elements in PP products; (2) new studies on Zn levels in cosmetic products for children; and (3) the creation of legislation to regulate the composition of PP products.
\end{abstract}

Keywords: Blush. Eye shadow. Face powder. Powdered paint. Atomic absorption spectrometry flame. Atomic absorption spectrometer with electrothermal atomization in a graphite oven.

\section{Introduction}

Cosmetics are substances used as personal care products to enhance or protect the appearance or mask the odor of the human body [1]. According to European Regulation (EC) No.
$1223 / 2009$ [2], the cosmetics are "any substance or mixture intended to be placed in contact with the external parts of the human body (epidermis, hair system, nails, lips, and external genital organs) or with the teeth and the mucous membranes of 


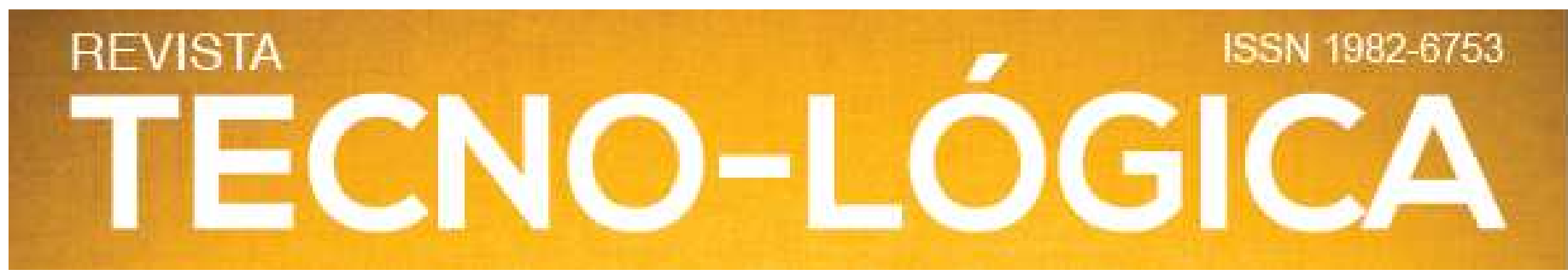

the oral cavity with a view exclusively or mainly to cleaning them, perfuming them, changing their appearance, protecting them, keeping them in good condition or correcting body odors" $[2]$.

During the last few decades, the use of cosmetic products has increased around the world [3]. Its products have been commonly used by millions of consumers of all types, regardless of age, socio-economic or cultural lifestyles around the world [4]. The increase in the consumption of these products has also been observed among children ( 0 to 10 years old).

As a result, there was an increase in the diversity of products and brands, and the lack of control over the composition, origin of ingredients applied in the composition, quality, among others is a growing concern. Cosmetic products used for children are as numerous as they are diverse. There are in the literature studies about children's consumption and exposure to cosmetic products [4-6]. However, very little information about the risks of these products is available, especially in relation to the inorganic composition. According to Bocca et al. [7], the composition of cosmetic products is rather complex and may contain hazardous bio-accumulative metals.

The most used analytical approach to the quantification of metal content in cosmetics, in the absence of official methods, is the digestion with acids $\left(\mathrm{HNO}_{3}\right)$ and $\mathrm{H}_{2} \mathrm{O}_{2}$ [8-11] followed by instrumental determination using inductively coupled plasma optical emission spectrometry (ICP OES) [12], atomic absorption spectrophotometer flame (FAAS) [9-11;13], inductively coupled plasma-mass spectrometry (ICP-MS) [14], or other techniques.

This study reports on the development of a simple and fast methodology for the digestion of cosmetic products. The aim of this study was to determine the concentration of potentially toxic elements as Nickel (Ni), Lead (Pb), Zinc (Zn), and Arsenic (As) in different cosmetics such as blush (BL), eyes shadow (SH), face powder (PO) and powdered paint for children (PP), using simple digestion methodologies like atomic absorption spectrometry flame (FAAS), and atomic absorption spectrometry in a graphite oven (GFAAS) techniques. The $\mathrm{Pb}$ and As were selected in this study because they are considered toxic even at low concentrations, and they can be bioaccumulated in the organism [7]. The $\mathrm{Ni}$ is involved in allergic dermatitis [15]. The $\mathrm{Zn}$ has been frequently used in cosmetic products, such as Zn oxide and Zn stearate [3]. 


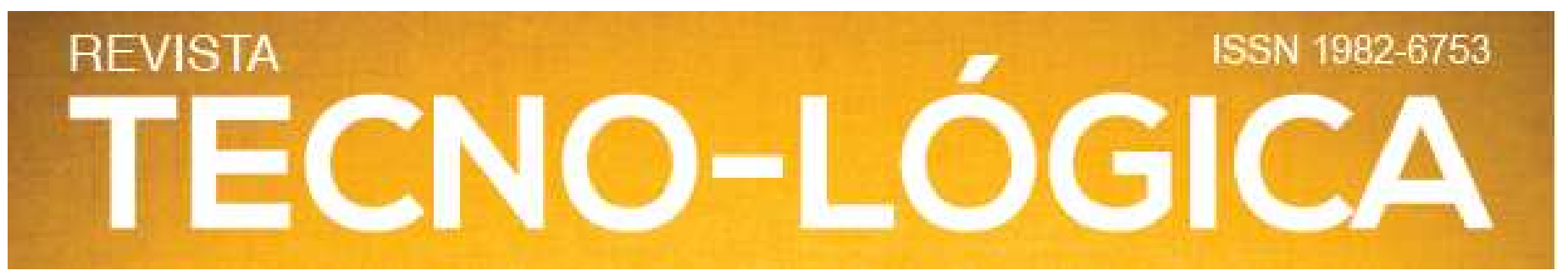

\section{Methodology}

\subsection{Cosmetic Product Samples}

A total of twelve cosmetic product samples (Table 1) were selected and purchased in local markets in Pato Branco, Paraná, Brazil. The samples analyzed in this work include BL, SH, PO, and PP. The BL, SH and PO selected samples were imported from China and the PP from Brazil.

The BL, SH, and PO samples were analyzed in two shades, light and dark. The nomenclature adopted was: BLl (light blush), BLd (dark blush), SHl (light eye shadow), SHd (dark eye shadow), POl (light face powder), and POd (dark face powder).

The PP samples were identified according to the colors: PPp (purple powdered paint), PPy (yellow powdered paint), PPb (blue powdered paint), PPo (orange powdered paint), PPpi (pink powdered paint), and PPg (green powdered paint). In table 1 are presented the identification of the samples analyzed in this work.
Table 1. Identification of cosmetic products

\begin{tabular}{c|c|c}
\hline $\begin{array}{c}\text { Identification } \\
\text { Sample }\end{array}$ & Cosmetic & Shade or Color \\
\hline BLl & Blush & Light \\
BLd & Blush & Dark \\
SHl & Eye shadow & Light \\
SHd & Eye shadow & Dark \\
POl & Face powder & Light \\
POd & Face powder & Dark \\
PPp & Powdered paint & Purple \\
PPy & Powdered paint & Yellow \\
PPb & Powdered paint & Blue \\
PPo & Powdered paint & Orange \\
PPpi & Powdered paint & Pink \\
PPg & Oreen paint & Prang \\
\hline
\end{tabular}

\subsection{Reagents and Solutions}

Standard solutions for calibration curves were prepared by serial dilution of commercial stock solutions $\left(1000 \mathrm{mg} \mathrm{L}^{-1}\right)$ of Grupo Química. The reagents $\mathrm{HNO}_{3}$ and $\mathrm{H}_{2} \mathrm{O}_{2}$ were of analytical grade unless otherwise specified. Ultra-pure water $(18 \mathrm{M} \Omega)$ was obtained from a Milli-Q purification system (Merk Millipore, Darmstadt, Germany). A Digital Ultrasonic Cleaner CD-4860 ultrasonic bath (Gnatus, São Paulo, Brazil) was used to sample sonication in methodology 2 . All laboratory glassware was previously decontaminated with $10 \%\left(\mathrm{v} \mathrm{v}^{-1}\right)$ of $\mathrm{HNO}_{3}$ 


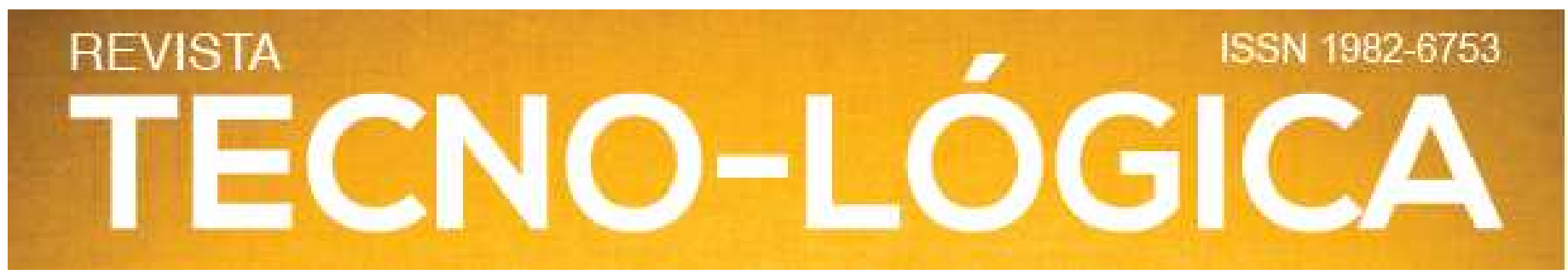

solution for 24 hours. Before use, these materials were rinsed abundantly with deionized water.

\subsection{Sample Preparation}

Initially, the cosmetic samples were dried (at $100^{\circ} \mathrm{C}$ ), until you get constant weight, grounded and homogenized. For sample digestion, two methodologies were applied. The methodology 1 used in this study was based on procedures recommended by Ullah et al [16] with some modifications, and the methodology 2 is a suggestion of this work.

Methodology 1 - After drying (at $100^{\circ} \mathrm{C}$ ) the cosmetic sample was calcined at $600^{\circ} \mathrm{C}$ for 2 hours [11]. After cooling to room temperature (at desiccator), the residual ashes $(\approx 0.100 \mathrm{~g}$ ) were digested with $2 \mathrm{~mL}$ of $\mathrm{HNO}_{3} 1 \mathrm{~mol} \mathrm{~L}^{-1}$ at $130^{\circ} \mathrm{C}$ in a digester block to about $1 \mathrm{~mL}$. Finally, the solution was quantitatively transferred to Falcon tubes and the volumes completed with ultra-pure water (MiliQ) up to $25 \mathrm{~mL}$ [14]. All experiment was carried out in triplicate $(n=3)$. Blank was treated in the same procedure. The solution obtained after digestion was used for analytical determinations, which were carried out in triplicate.

Methodology 2 - A pre-digestion with $1 \mathrm{~mL}$ of $35 \%(\mathrm{v} \mathrm{v}$ $\left.{ }^{1}\right) \mathrm{H}_{2} \mathrm{O}_{2}$ and $0.100 \mathrm{~g}$ of cosmetic sample (1 hour of repose) was performed after drying $\left(100^{\circ} \mathrm{C}\right)$. Subsequently, it was added $1 \mathrm{~mL}$
$\mathrm{HNO}_{3}$ and the solution was put into the ultrasonic bath for 30 minutes at $60^{\circ} \mathrm{C}$. After the vessel was to a digester block at $120^{\circ} \mathrm{C}$ to about $1 \mathrm{~mL}$. Finally, the solution was quantitatively transferred to Falcon tubes and the volumes completed with ultra-pure water (MiliQ) up to $25 \mathrm{~mL}$. All experiment was carried out in triplicate $(n=3)$. Blank was treated in the same procedure. The solution obtained after digestion was used for analytical determinations, which were carried out in triplicate.

\subsection{Instrumental Parameters}

$\mathrm{Ni}, \mathrm{Pb}$, and $\mathrm{Zn}$ were quantified by FAAS and As was quantified by GFAAS using a Perkin Elmer PinAAcle 900T spectrometer (Norwalk, CT, USA) operated at $232.00 \mathrm{~nm}(\mathrm{Ni})$, $283.31 \mathrm{~nm}(\mathrm{~Pb}), 213.86 \mathrm{~nm}(\mathrm{Zn})$, and $193.70 \mathrm{~nm}(\mathrm{As})$.

The oven temperature program applied in GFAAS is given in Table 2. A monoelementary hollow cathode lamp from Perkin Elmer was used. The flame composition was airacetylene. Calibration curves of the $\mathrm{Ni}, \mathrm{Zn}, \mathrm{Pb}$, and $\mathrm{As}$ analytes were prepared using standard solutions. 


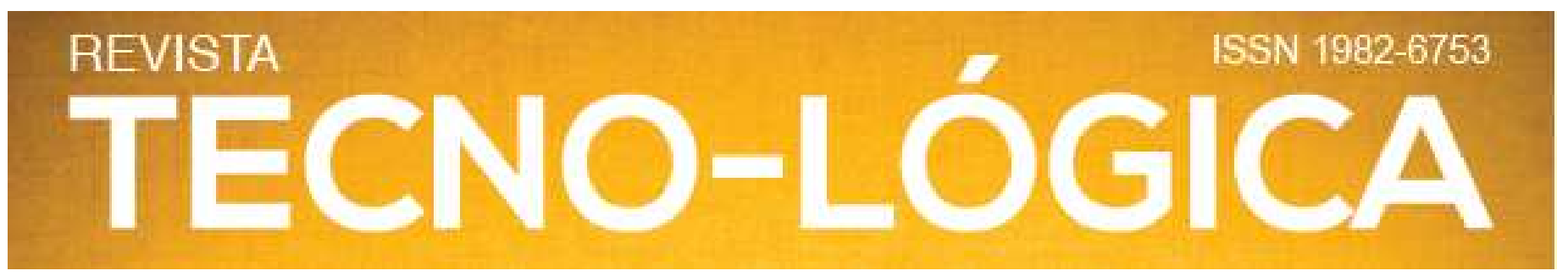

Table 2. GFAAS program for As analysis

\begin{tabular}{l|c|c|c}
\hline Step & $\begin{array}{r}\text { Temperature } \\
\left({ }^{\mathbf{O}} \mathbf{C}\right)\end{array}$ & $\begin{array}{c}\text { Time ramp } \\
(\mathbf{s})\end{array}$ & Time hold \\
& 110 & 1 & 30 \\
\hline Drying & 130 & 15 & 30 \\
Drying & 1200 & 10 & 20 \\
Pyrolysis & 2000 & 0 & 5 \\
Atomization & 2450 & 1 & 3 \\
Cleaning & & & \\
\hline
\end{tabular}

\subsection{Detection and Quantification Limits}

The limits of detection (LOD) and quantification (LOQ) were calculated following the IUPAC approach [15], which consists in analyzing the blank sample, calculating the standard deviation and expressing the result as the mean plus 3- and 10times standard deviation for LOD and LOQ, respectively:

$$
\begin{aligned}
& \mathrm{LOD}=\frac{3 \times \mathrm{SD}^{\text {blank }}}{\mathrm{b}} \\
& \mathrm{LOQ}=\frac{10 \times \mathrm{SD}^{\text {blank }}}{\mathrm{b}}
\end{aligned}
$$

where SD is the standard deviation for ten blank measurements (using an empty platform) and b is the angular coefficient of the calibration curve.

\subsection{Moisture and Ashes Content Determination}

After drying at $100^{\circ} \mathrm{C}$, the cosmetic sample was calcined in a muffle oven at $600^{\circ} \mathrm{C}$ for 2 hours. Subsequently, the calcined sample was cooled in a desiccator. Finally, the mass of the sample was measured, and the moisture content (MC) and the ashes content (AC) were calculated using the formulas:

$$
\begin{aligned}
& \mathrm{MC}=\frac{\text { Mwet }- \text { Mdry }}{\text { Mdry }} \times 100 \\
& \mathrm{AC}=\frac{\text { Mdry }}{\text { Mwet }} \times 100
\end{aligned}
$$

where MC is the moisture content of the sample, Mwet is the wet weight and Mdry is the dry weight.

\section{Results and Discussion}

\subsection{Instrumental Parameters}

The inorganic elements may exist as impurities in the raw ingredients or as products of the manufacturing process of cosmetics [18]. Among the harmful elements that elicit concern are include $\mathrm{Ni},[19] \mathrm{Pb}, \mathrm{As},[20]$ and $\mathrm{Zn}[18-21]$.

The $\mathrm{Ni}, \mathrm{Pb}$, and $\mathrm{As}$ are naturally present in iron oxide pigments and other raw materials used in the cosmetic products 


\section{REVISTA}

during the manufacturing $[7,22]$. Although, currently there is no

regulation on the tolerances of the toxic elements in iron oxide

pigment, the quantification of the $\mathrm{Pb}, \mathrm{As}$, and $\mathrm{Ni}$ contents in

cosmetic products are of great importance for the control of its

quality and for the safety of its applications [22].

Table 3. Results obtained $\left(\mathrm{mg} \mathrm{L}^{-1}\right)$ in the determination of $\mathrm{Ni}, \mathrm{Pb}, \mathrm{Zn}$ and As in cosmetic products by two methodologies and employing the FAAS and GFAAS

\begin{tabular}{|c|c|c|c|c|c|c|c|c|}
\hline \multirow{3}{*}{ Samples } & \multicolumn{2}{|c|}{$\mathbf{N i}$} & \multicolumn{2}{|c|}{$\mathbf{P b}$} & \multicolumn{2}{|c|}{ Zn } & \multicolumn{2}{|c|}{ As } \\
\hline & \multicolumn{8}{|c|}{ - } \\
\hline & M1 & M2 & M1 & M2 & M1 & M2 & M1 & M2 \\
\hline $\mathrm{BLl}$ & $<0.038$ & $<0.025$ & $<0.023$ & $<0.027$ & $<0.334$ & $<0.088$ & $<0.049$ & $<0.008$ \\
\hline BLd & $<0.038$ & $<0.025$ & $<0.023$ & $<0.027$ & $<0.334$ & $<0.088$ & $<0.049$ & $<0.008$ \\
\hline SHI & $<0.038$ & $<0.025$ & $<0.023$ & $<0.027$ & $<0.334$ & $<0.088$ & $<0.049$ & $<0.008$ \\
\hline SHd & $<0.038$ & $<0.025$ & $<0.023$ & $<0.027$ & $<0.334$ & $<0.088$ & $<0.049$ & $<0.008$ \\
\hline POl & $<0.038$ & $<0.025$ & $<0.023$ & $<0.027$ & $<0.334$ & $<0.088$ & $<0.049$ & $<0.008$ \\
\hline POd & $<0.038$ & $<0.025$ & $<0.023$ & $<0.027$ & $<0.334$ & $<0.088$ & $<0.049$ & $<0.008$ \\
\hline $\mathrm{PPp}$ & $<0.038$ & $<0.025$ & $<0.023$ & $<0.027$ & $210 \pm 49$ & $45 \pm 2$ & $<0.049$ & $<0.008$ \\
\hline PPy & $<0.038$ & $<0.025$ & $<0.023$ & $<0.027$ & $53 \pm 65$ & $2 \pm 1$ & $<0.049$ & $<0.008$ \\
\hline $\mathrm{PPb}$ & $<0.038$ & $<0.025$ & $<0.023$ & $<0.027$ & $442 \pm 32$ & $120 \pm 34$ & $<0.049$ & $<0.008$ \\
\hline PPo & $<0.038$ & $<0.025$ & $<0.023$ & $<0.027$ & $<0.334$ & $<0.088$ & $<0.049$ & $<0.008$ \\
\hline PPpi & $<0.038$ & $<0.025$ & $<0.023$ & $<0.027$ & $103 \pm 23$ & $50 \pm 21$ & $<0.049$ & $<0.008$ \\
\hline $\mathrm{PPg}$ & $<0.038$ & $<0.025$ & $<0.023$ & $<0.027$ & $<0.334$ & $<0.088$ & $<0.049$ & $<0.008$ \\
\hline
\end{tabular}

$\mathrm{M} 1$ = methodology 1 and M2 = methodology 2 mean \pm standard deviation $(\mathrm{n}=3)$.

The focus of this study is on elements with known significant toxicological properties such as $\mathrm{Ni}, \mathrm{Pb}$, and As. Also, the $\mathrm{Zn}$ is an essential element, and at high levels may cause adverse effects on human health in cosmetic products. According to da Costa et al. [12], $\mathrm{Zn}$ is an essential micronutrient and its toxicity is rare it can be easily found in facial cosmetics in the form of oxides [12], commonly employed in cosmetics for blocking ultraviolet light or coloring pigments [21].

TECNO-LÓGICA, Santa Cruz do Sul, v. 25, n 1, p. 59-72, jul./dez. $2021^{\text {A matéria publicada nesse periódico é licenciada sob forma de uma }}$ http://creativecommons.org/licenses/by/4.0/ 


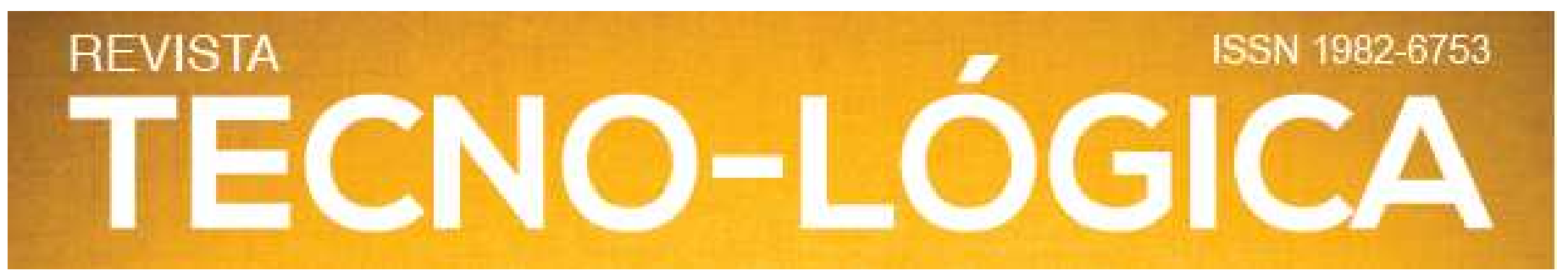

The cosmetic samples presented $\mathrm{Ni}, \mathrm{Pb}$, and $\mathrm{As}$ concentration below the LOD (Table 3).

For all elements, $\mathrm{Ni}, \mathrm{Pb}, \mathrm{Zn}$, and $\mathrm{As}$, the values varied according to the methodology used in the sample digestion. In general, the smallest LOD was observed by methodology 2 . The pre-digestion with $\mathrm{H}_{2} \mathrm{O}_{2}$ instead of calcination of the sample at $600^{\circ} \mathrm{C}$ for 2 hours is the main difference between the methodologies.

The Ni LOD obtained by FAAS according to methodology 1 and 2, were 0.038 and $0.025 \mu \mathrm{g} \mathrm{L}^{-1}$, respectively. This Ni results indicate that the analytical technique has no analytical sensibility to the Ni determination in the $\mathrm{BL}, \mathrm{SH}, \mathrm{PO}$ and PP cosmetic samples analyzed in this work. Thus, it cannot be said that there is no $\mathrm{Ni}$ in the analyzed samples.

The results obtained by Volpe et al. [23] shown that the $\mathrm{Ni}$ concentrations in eye shadows from Italy, China and USA varied from $0.022 \pm 0.002$ to $4.25 \pm 0.06 \mu \mathrm{g} \mathrm{L}^{-1}$. In this study, the determination was performed by inductively coupled plasma-mass spectrometry (ICP MS).

The mean \pm standard deviation values of $\mathrm{Ni}$ concentration in face powder and lipstick obtained by Sani et al. [11] ranges between $8.09 \pm 4.79$ and $8.82 \pm 4.19 \mathrm{mg} \mathrm{kg}^{-1}$ and $8.24 \pm 3.29$ and $5.15 \pm 4.19 \mathrm{mg} \mathrm{kg}^{-1}$, respectively. In this study, the cosmetic samples were acquired at different shopping malls and markets in Kano Metropolis, and the samples were digested and analyzed using FAAS.

Bocca et al. [19] determined the levels of $\mathrm{Ni}$ and other potentially allergenic metals in Ni-tested commercial body creams by sector field inductively coupled plasma mass spectrometry (SF ICP MS). Contado et al. [24] analyzed nine cheap eye shadow products by GFAAS to quantify Ni contents.

Similar to the results obtained for $\mathrm{Ni}$ were observed to $\mathrm{Pb}$ and As. In Table 3 all the samples digested by methodology 1 and 2 presented $\mathrm{Pb}$ and As contents below of the LOD. The LOD to $\mathrm{Pb}$ by FAAS range between 0.023 and $0.027 \mathrm{mg} \mathrm{L}^{-1}$ and to As by GFAAS range between 0.049 and $0.008 \mathrm{mg} \mathrm{L}^{-1}$ to methodologies 1 and 2, respectively.

The $\mathrm{Pb}$ concentrations in eye shadows varied from $0.57 \pm$ 0.01 to $81.50 \pm 0.89 \mu \mathrm{g} \mathrm{g}^{-1}$ in results obtained by Volpe et al. [23] to eye shadows from China, Italy, and USA using a FAAS. Sani et al. [11] obtained $\mathrm{Pb}$ concentrations in face powder between $0.13 \pm 0.042$ and $0.17 \pm 0.12 \mathrm{mg} \mathrm{kg}^{-1}$.

The $\mathrm{Pb}$ potentially affects almost every system, such as the reproductive, neurological, hematopoietic, hepatic, and renal systems in the human body. The $\mathrm{Pb}$ can even cause cancer due to excessive accumulation in the human body [25]. Exposure to As can cause a variety of diseases, including skin lesions, neurological and respiratory effects, atherosclerosis, and several types of cancer [26]. 


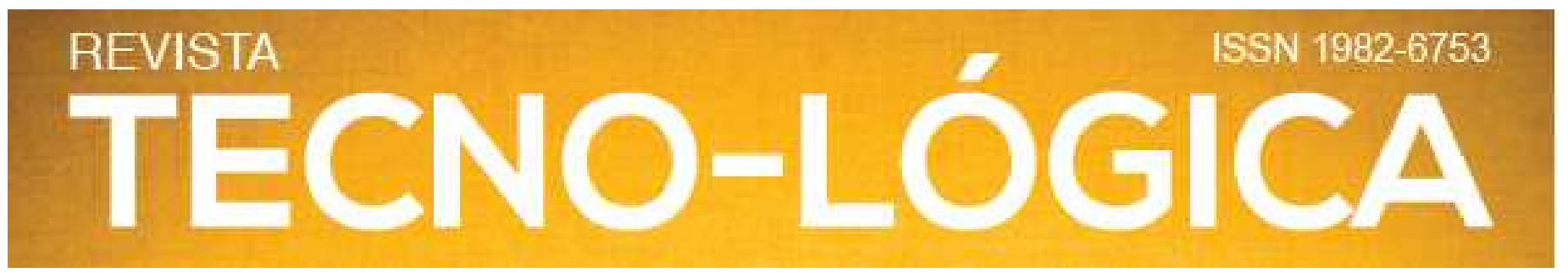

Hepp et al. [14] reported total amounts of As in 150 cosmetic products of 12 types sold on the USA market, and overall, cosmetic products were found to contain mean values of $0.21 \mathrm{mg} \mathrm{kg}^{-1}$ As. Jelić et al. [13] examined the presence of As in 10 samples of lipsticks and 8 samples of nail polishes, and the results show this element was very low or under the analytical methods limit in both samples.

From Table 3, $\mathrm{Zn}$ concentration in $\mathrm{BL}, \mathrm{SH}$, and $\mathrm{PO}$ presented values below of the LOD, $0.334 \mathrm{mg} \mathrm{L}^{-1}$ to methodology 1 and $0.088 \mathrm{mg} \mathrm{L}^{-1}$ to methodology 2 . However, in the PPpi, PPp, PPy and PPb samples the $\mathrm{Zn}$ concentrations range between $53 \pm 65$ and $442 \pm 32 \mathrm{mg} \mathrm{L}^{-1}$ (methodology 1), and $2 \pm$ 1 and $120 \pm 34 \mathrm{mg} \mathrm{L}^{-1}$ (methodology 2).

The high concentrations of $\mathrm{Zn}$ in some of the PP samples are probably due to the use of $\mathrm{Zn}$ oxide, an inorganic pigment [10]. The $\mathrm{Zn}$ oxide is a white pigment commonly employed in cosmetic formulations. The white pigments are required for skin protection during cosmetic use [27], and to block ultraviolet radiation [21]. Others substances, such as titanium dioxide can be used with the same function [27]. In PPO samples, values below the LOD may be associated with the use of another ingredient with the same function as $\mathrm{Zn}$ oxide. The powdered blushes do not contain much $\mathrm{Zn}$ oxide [28], in other words, this affirmation corroborate with the results presented in Table 3.
These results reinforce the importance of new studies about the chemical characterization of cosmetic products for children. It is more results about the qualitative and quantitative composition and that include a greater diversity of cosmetic products for children. Based on these data, new legislation could then be created to regulate the composition of products intended for application for children.

Several government and industry sources have established maximum limits for chemical elements in cosmetics. However, there is a lack of standardization between them around the world. In some cases, the limits are established based on the concentrations of elements commonly found in cosmetics sold in each country [3].

In Brazil, the Agência Nacional de Vigilância Sanitária (ANVISA) is responsible for the marketing authorization of cosmetics, and supervises and establishes standards for manufacturers, checking the production process, in addition to regularly publish a list of irregular cosmetic products [29-33]. The ANVISA also provides the national limits of chemical elements in cosmetic products. However, there is no specific legislation for children's cosmetics, such as PP.

According to the ANVISA (ANVISA, N॰44/2012) [34], the maximum level of impurities allowed for artificial organic dyes in cosmetics is $3 \mathrm{mg} \mathrm{kg}^{-1}$ for $\mathrm{As}$ (as $\mathrm{As}_{2} \mathrm{O}_{3}$ ), $20 \mathrm{mg} \mathrm{kg}^{-1}$ for $\mathrm{Pb}$ and $100 \mathrm{mg} \mathrm{kg}^{-1}$ for other metals. The Cosmetic Products 


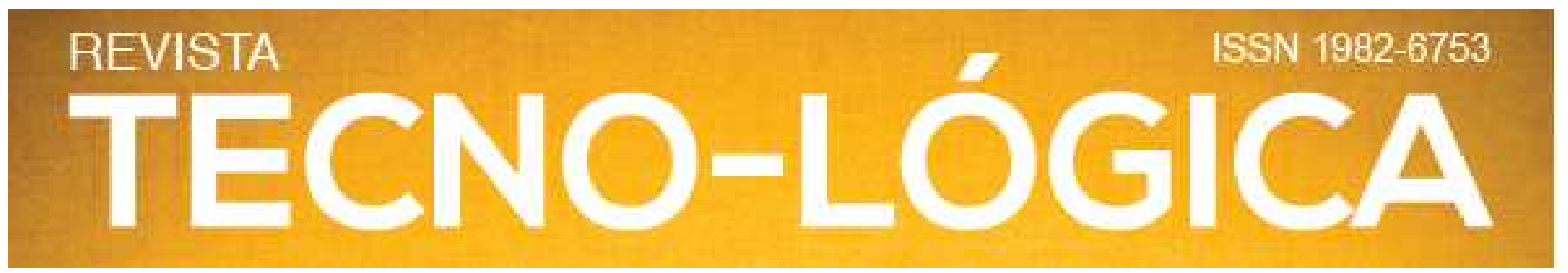

Directive 76/768/EEC (Art.2) (EU, 1976) [35] prohibits the presence of As in all types of cosmetics, being considered a toxic element to humans. Brazil provides a national limit of $20 \mu \mathrm{g} \mathrm{g}^{-1}$ of $\mathrm{Pb}$ in eye products, lipsticks and lip pencils [34].

Most of the methods reported in the literature for elemental determination in cosmetics involve the sample preparation step and subsequent determination of elements by spectrometric techniques [3]. About the sample preparation, Sani et al. [11] used ashed samples, $\mathrm{HNO}_{3}$ and a hot plate in the digestion of cosmetic products. Sainio et al. [15] used $\mathrm{HNO}_{3}$ and $\mathrm{HCl}$, and the samples were heated slowly in a sand bath nearly to dryness. Wang et al. [20] used a microwave assisted and $\mathrm{HNO}_{3}$. Others methodologies of cosmetic sample preparation are found in the literature $[9,10,13,19,21-23,36]$. The diversity between the sample preparation methodologies proposed in the literature motivated in this work the comparison between two different methodologies: the methodology 1 (methodology proposed by Ullah et al. [16] with some modifications) and the methodology 2 (methodology proposed in this study).

The main differences among the methodologies are that the methodology 2 does not require a long time of sample pretreatment as methodology 1,2 hours of calcination plus the time of cooling to room temperature. In methodology 2 , the sample pretreatment was replaced by pre-digestion with $1 \mathrm{~mL}$ of $35 \%\left(\mathrm{v} \mathrm{v}^{-1}\right) \mathrm{H}_{2} \mathrm{O}_{2}$ for 1 hour. Consequently, methodology 2 allows us to digest a larger number in less time, even if it has one more step (ultrasonic bath for 30 minutes).

Another important difference among the methodologies is the volume of $\mathrm{HNO}_{3}$. In methodology 2 half the volume (1 $\mathrm{mL})$ of methodology $1(2 \mathrm{~mL})$ is used.

In general, methodology 1 consumes more energy and acid $\left(\mathrm{HNO}_{3}\right)$, and the proposed methodology (methodology 2) is faster and cheaper, and it can be performed with instruments commonly found in laboratories.

The methodology proposed in this study (methodology 2) was compared with some methodologies applied in the cosmetic digestion $[11,20,37]$. The methodology proposed to the consumers a lower volume of reagents, generate less waste volume, does not use reagent with high hazard (HF), and employs equipment for easy acquisition and maintenance, such as ultrasonic bath and digester block.

\subsection{Moisture and Ashes Content Determination}

In Figure 1 are presented the moisture and ashes content in $\mathrm{BL}, \mathrm{SH}, \mathrm{PO}$ and $\mathrm{PP}$ samples. 


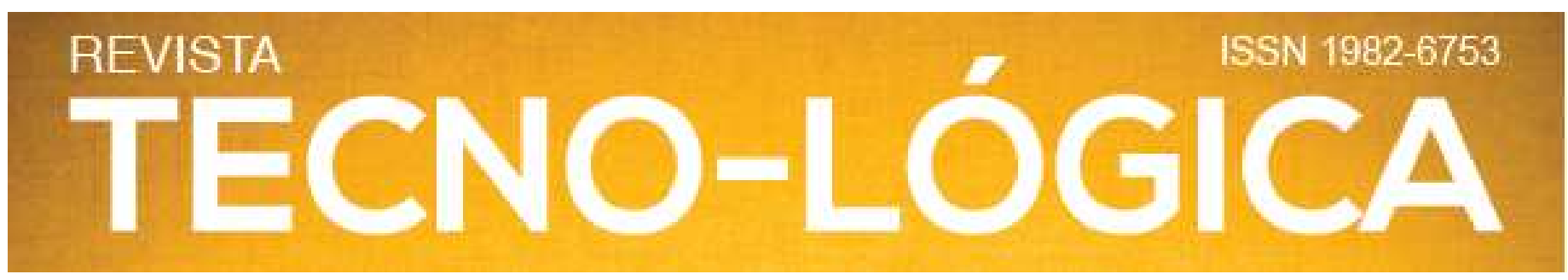

(a)

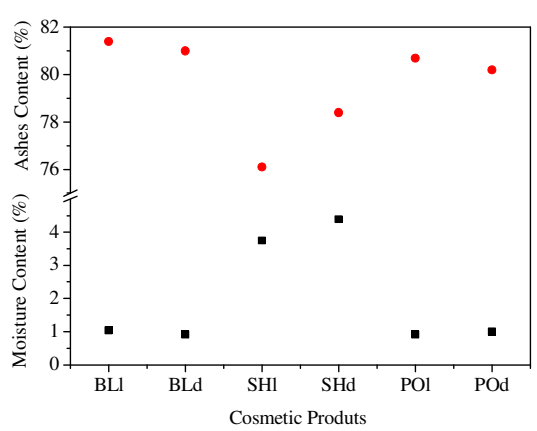

(b)

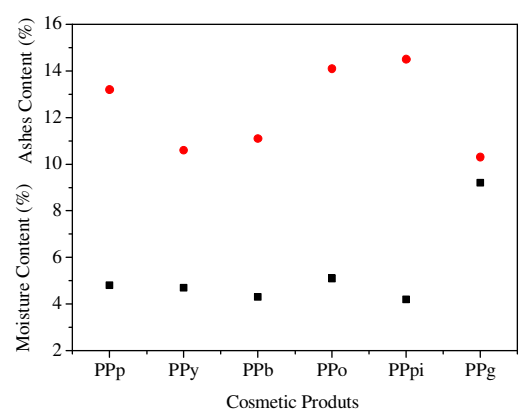

Figure 1. Moisture (घ) and ashes (•) content in (a) BL, SH, and PO samples, and in (b) PP samples.

As shown in Figure 1, the moisture content varied from 0.92 to $9.20 \%$. The highest moisture contents were observed to PP (Figure 1b). This result indicates that in general the cosmetic products, $\mathrm{BL}, \mathrm{SH}, \mathrm{PO}$, and $\mathrm{PP}$ have a small amount of water in their composition.

The ashes are the residue obtained after combustion under specific conditions, and are formed by oxides resulting from the combustion of the original mineral material. Thus, the determination of the ashes content in cosmetic products can be used as an indicator of the amount of mineral salts [38].

The BL, SH, and PO presented ashes content between 71.6 to $81.4 \%$ (Figure 1a), and in the PP the ashes contents varied from 10.3 to $14.5 \%$ (Figure $1 \mathrm{~b}$ ). These results indicate that the cosmetic products, $\mathrm{BL}, \mathrm{SH}$, and $\mathrm{PO}$ present the highest mineral content, mainly oxides, if compare to PP samples. These results confirm that the cosmetic sample characterized have matrices with varied compositions. According to Atz and Pozebon [39], the pigments more frequently used in cosmetics are in general oxides, such as iron oxide, chromium oxide, titanium dioxide, $\mathrm{Zn}$ oxide. The micas, aluminosilicates coated with titanium dioxide, iron oxide, or titanium dioxide, also are commonly used in the production of cosmetics because contain some pigments capable of producing pearly effects [40].

The SH is available in several colors, and pigments such as iron oxide, titanium dioxide, copper powder, and chromium oxide, which are commonly used in this cosmetic [39]. Moreover, substances such as titanium dioxide, bismuth oxychloride, and micas may be used to provide various effects to these products. PO usually uses iron oxides as the main pigment, but other inorganic pigments, such as ultramarines, chrome oxide, and chrome hydrate, also may be used [28]. The iron oxide is also a common dye in BL [11]. 


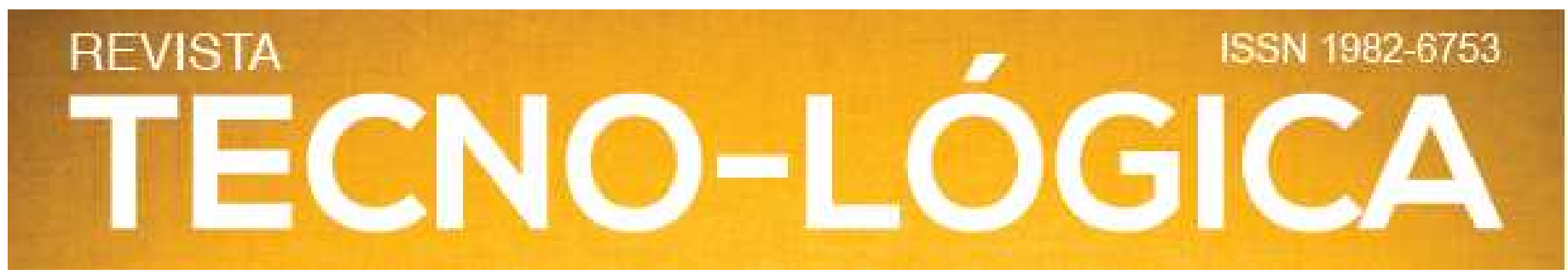

\section{Conclusions}

The proposed methodology consumes less energy and acid $\left(\mathrm{HNO}_{3}\right)$, is faster and cheaper, and it can be performed with instruments commonly found in laboratories.

From the results obtained, $\mathrm{Ni}, \mathrm{As}, \mathrm{Zn}$, and $\mathrm{Pb}$ were not detected in the $\mathrm{BL}, \mathrm{SH}$, and $\mathrm{PO}$ products from China, and $\mathrm{Ni}, \mathrm{As}$, and $\mathrm{Pb}$ were not detected in $\mathrm{PP}$ from Brazil.

The application of FAAS, preceded by sample preparation using the methodologies 1 and 2, has allowed the Zn quantification in PP samples. The $\mathrm{Zn}$ was found at concentrations between $2 \pm 1$ $\mathrm{mg} \mathrm{L}^{-1}$ and $442 \pm 32 \mathrm{mg} \mathrm{L}^{-1}$.

It is important to avoid the use of cosmetic products by children. ANVISA recommends that kids use only children's products [41]. However, as the commercialization of cosmetic products for this public has grown in recent years, the following actions are recommended:

(1) Regular monitoring of potentially toxic elements in PP products;

(2) New studies about the Zn levels in cosmetic products for children;

(3) The creation of legislation to regulate the composition of PP products.

\section{Acknowledgments}

The authors thank the Universidade Tecnológica Federal do Paraná (UTFPR) - Pato Branco, the Ministry of Education of Brazil and acknowledge the technical support provided, the Central de Análises of UTFPR for the support on FAAS and GFAAS spectroscopy. This work was financed in part by the Coordenação de Aperfeiçoamento de Pessoal de Nível Superior Brasil (CAPES), Fundação Araucária, Financiadora de Estudos e Projetos (FINEP) and Conselho Nacional de Desenvolvimento Científico Tecnológico (CNPq).

\section{PRODUTOS COSMÉTICOS PARA CRIANÇAS E}

\section{ADULTOS - DETERMINAÇÃO DOS TEORES DE As, Ni,}

\section{Pb E Zn}

RESUMO: O objetivo deste trabalho foi determinar a concentração de elementos potencialmente tóxicos em diferentes produtos cosméticos, usando metodologias de digestão simples, acessíveis e técnicas espectroscópicas. Um total de doze produtos foram selecionados, comprados e analisados, os quais incluem blush (BL), sombra para os olhos (SH), pó facial (PO) e tinta em pó para crianças (PP). As amostras foram secas (a $100^{\circ} \mathrm{C}$ ), trituradas e homogeneizadas. Para digestão duas metodologias foram empregadas. Os teores de $\mathrm{Ni}, \mathrm{Pb}$ e $\mathrm{Zn}$ foram quantificados 


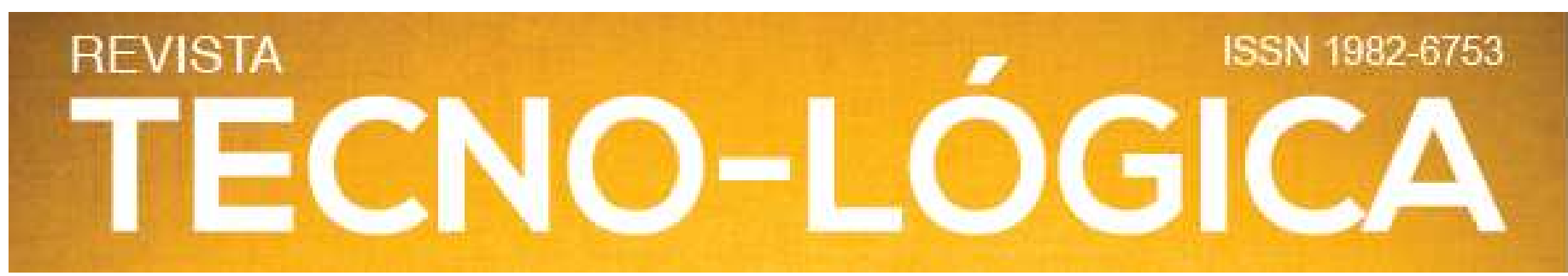

por espectrometria de absorção atômica com chama (FAAS), e os teores de As por espectrometria de absorção atômica com atomização eletrotérmica em forno de grafite (GFAAS). Em geral, as amostras apresentaram teores abaixo do limite de detecção (LOD) para Ni, Pb, As e Zn. No entanto, algumas amostras de PP apresentaram teores de $\mathrm{Zn}$ entre $2 \pm 1$ e $442 \pm 32 \mathrm{mg} \mathrm{L}^{-1}$. Esse resultado deve-se provavelmente ao uso de alguns pigmentos naturais ou inorgânicos, e sugerem as seguintes ações: (1) monitoramento regular de elementos potencialmente tóxicos em produtos de PP; (2) novos estudos sobre os níveis de $\mathrm{Zn}$ em produtos cosméticos para crianças; e (3) a criação de legislação para regular a composição dos produtos de PP.

Palavras-chave: Blush. Sombra. Pó compacto. Tinta em pó. Espectrometria de absorção atômica com chama. Espectrometria de absorção atômica com atomização eletrotérmica em forno de grafite.

\section{References}

[1] MASSADEH, A. M.; EL-KHATEEB, M. Y.; IBRAHIM, S. M.; Evaluation of $\mathrm{Cd}, \mathrm{Cr}, \mathrm{Cu}, \mathrm{Ni}$ and $\mathrm{Pb}$ in selected cosmetic products from Jordanian, Sudanese, and Syrian markets, Public Health, Vol. 149, p 130-137, 2017.

[2] EU, 2009. Regulation (EC) No 1223/2009 of the European Parliament and of the Council of 30 November 2009 on Cosmetic Products. Available at: https://eurlex.europa.eu/legal-content/EN/ALL/?uri=CELEX\%3A32009R1223, Accessed at: $04 / 07 / 2020$
[3] MESKO, M. F.; NOVO, D. L. R.; COSTA, V. C.; HENN, A. S.; FLORES, E. M. M.; Toxic and potentially toxic elements determination in cosmetics used for make-up: A critical review, Analytica Chimica Acta, Vol. 1098, p. 1-26, 2020.

[4] GOMEZ-BERRADA, M. P.; FICHEUX, A. S.; GUILlOU, S.; BERGE, C.; JAVEL, D.; ROUDOT, A. C.; FERRET, P. J.; Consumption and exposure assessment to cosmetic products for children under 2 years old, Food Chemical Toxicology, Vol. 105, p. 151-160, 2017.

[5] FICHEUX, A. S.; BERNARD, A.; CHEVILlotTe, G.; DORNIC, N.; ROUDOT, A. C; Probabilistic assessment of exposure to hair cosmetic products by the French population. Food and Chemical Toxicology, Vol. 92, p. 205-216, 2016a.

[6] FICHEUX, A. S.; DORNIC, N.; BERNARD, A.; CHEVIllOTTE, G.; ROUDOT, A. C; Probabilistic assessment of exposure to cosmetic products by French children aged 0-3 years. Food and Chemical Toxicology, Vol. 94, p. 85-92, $2016 b$.

[7] BOCCA, B.; PINO, A.; ALIMONTI, A.; FORTE, G.; Toxic metals contained in cosmetics: A status report. Regulatory Toxicology and Pharmacology, Vol. 68, no 3, p. 447-467, 2014.

[8] CAPELLI, C.; FOPPIANO, D.; VENTURELLI, G.; CARLINI, E.; MAGI, E.; IANNI, C.; Determination of Arsenic, Cadmium, Cobalt, Chromium, Nickel and lead in cosmetic face-powders: optimization of extraction and validation. Analytical Letters, Vol. 47, nº 7, p. 1201-1209, 2014.

[9] FARURUWA, M. D.; BARTHOLOMEW, S. P.; Study of heavy metals content in facial cosmetics obtained from open markets and superstores within Kaduna metropolis, Nigeria. American Journal of Chemistry and Application, Vol. 1, n 2 , p. 27-33, 2014.

[10] IWEGBUE, C. M. A; BASSEY, F. I.; OBI, B.; TESI, G. O.; MARTINCIGH, B. S.; Concentrations and exposure risks of some metals in facial cosmetics in Nigeria. Toxicology Reports, Vol. 3, p. 464-472, 2016. 


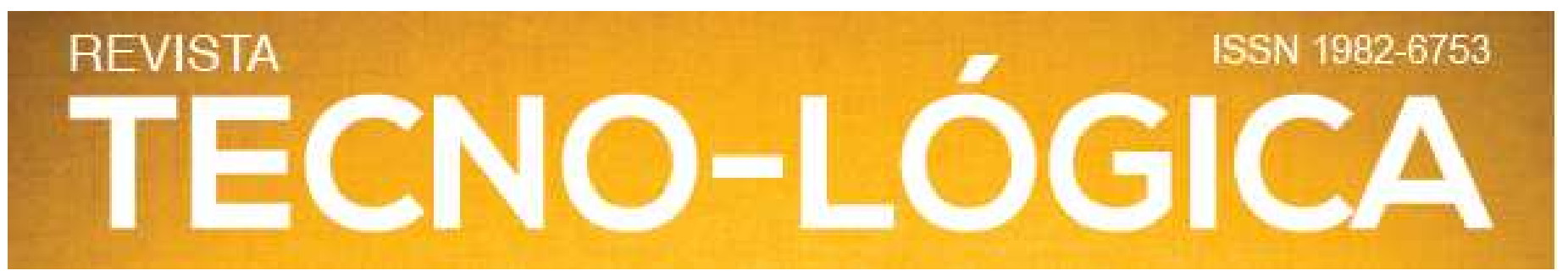

[11] SANI, A.; GAYA, M. B.; ABUBAKAR, F. A.; Determination of some heavy metals in selected cosmetic products sold in kano metropolis, Nigeria. Toxicology Reports, Vol. 3, p. 866-869, 2016.

[12] DA COSTA, W. V. O. C.; DA SILVA, C. S.; FIGUEIREDO, J. F. D.; NÓBREGA, J. A.; PAIM, A. P. S.; Direct analysis of deodorants for determination of metals by inductively coupled plasma optical emission spectrometry. Journal of Pharmaceutical and Biomedical Analysis, Vol. 155, p. 247-252, 2018.

[13] JELIĆ, D.; ANTUNOVIĆ, V.; EREROVIOVIĆ, M.; Arsenic and Mercury Content Determination in Commercial Cosmetics Products by Atomic Absorption Spectroscopy. Quality of Life, Vol. 8, p. (1-2) (23-26), 2017.

[14] HEPP, N. M.; MINDAK, W. R.; GASPER, J. W.; THOMPSON, C. B.; BARROWS, J. N.; Survey of cosmetics for arsenic, cadmium, chromium, cobalt, lead, mercury, and nickel content. Journal of Cosmetic Science, Vol. 65, p. 125$145,2014$.

[15] SAINIO, E. L.; JOLANKI, R.; HAKALA, E.; KANERVA, L.; Metals and arsenic in eye shadows. Contact Dermatitis, Vol. 42, p. 5-10, 2000

[16] ULLAH, H.; ANÓNIMO, S.; FOZIA, R. A.; WASEEM, A.; ZUBAIR, S.; ADNAN, M.; AHMAD, I.; Comparative study of heavy metals content in cosmetic products of different countries marketed in Khyber Pakhtunkhwa, Pakistan. Arabian Journal of Chemistry, Vol. 10, p. 10-18, 2017.

[17] MCNAUGHT, A. D.; WILKINSON, A.; NIC, M.; JIRAT, J.; KOSATA, B.; JENKINS, A.; IUPAC. Compendium of Chemical Terminology, (the" Gold Book"), 1997. Available at: http://www.chemsoc.org/chembytes/golbook/, Accessed at: 04/ 07/ 2020.

[18] NG, S. Y.; DEWI, F.; WANG, J.; SIM, L. P.; SCHIN, R. Y. C.; LEE, T. K.; Development of cosmetic cream certified reference material: certification of lead, mercury and arsenic mass fractions in cosmetic cream. International Journal of Mass Spectrometry, Vol. 389, p. 59-65, 2015.
[19] BOCCA, B.; FORTE, G.; PETRUCCI, F.; CRISTAUDO, A.; Levels of nickel and other potentially allergenic metals in Ni-tested commercial body creams. Journal of Pharmaceutical and Biomedical Analysis, Vol. 44, p. 11971202,2007

[20] WANG, W.; BAO, N.; YUAN, W.; SI, N.; BAI, H.; LI, H.; ZHANG, Q.; Simultaneous determination of lead, arsenic, and mercury in cosmetics using a plastic based disposable electrochemical sensor. Microchemical Journal, Vol. 148, p. 240-247, 2019.

[21] CHA, N. R.; LEE, J. K.; LEE, Y. R.; JEONG, H. J.; KIM, H. K.; LEE, S. Y.; Determination of Iron, Copper, Zinc, Lead, Nickel and Cadmium in Cosmetic Matrices by Flame Atomic Absorption Spectroscopy. Analytical Letters, Vol. 43, p. $259-268,2010$.

[22] XU, Y.; ZHOU, J.; WANG, G.; ZHOU, J.; TAO, G.; Determination of trace amounts of lead, arsenic, nickel and cobalt in high-purity iron oxide pigment by inductively coupled plasma atomic emission spectrometry after iron matrix removal with extractant-contained resin. Analytica Chimica Acta, Vol. 584, p. 204-209, 2007.

\section{[23] VOLPE, M. G.; NAZZARO, M.; COPPOLA, R.; RAPUANO, F.;} AQUINO, R. P.; Determination and assessments of selected heavy metals in eye shadow cosmetics from China, Italy, and USA. Microchemical Journal, Vol. 101, p. $65-69,2012$.

[24] CONTADO, C.; PAGNONI, A.; A new strategy for pressed powder eye shadow analysis: Allergenic metal ion content and particle size distribution. Science of the Total Environment, Vol. 432, p. 173-179, 2012.

[25] AL-SALEH, I.; AL-ENAZI, S.; SHINWARI, N.; Assessment of lead in cosmetic products. Regulatory Toxicology and Pharmacology, Vol. 54, p. 105$113,2009$.

[26] BHOWMICK, S.; PRAMANIK, S.; SINGH, P.; MONDAL, P.; CHATTERJEE, D.; NRIAGU, J.; Arsenic in ground water of West Bengal, India:

TECNO-LÓGICA, Santa Cruz do Sul, v. 25, n. 1, p. 59-72, jul./dez. 2021

matéria publicada nesse periódico é licenciada sob forma de uma Licença Creative Commons - Atribuição 4.0 Internacional http://creativecommons.org/licenses/by/4.0/

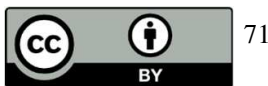




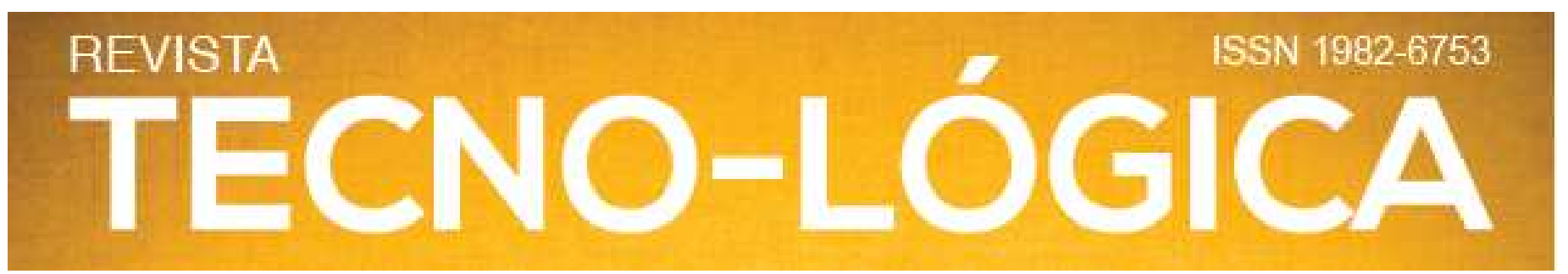

are view of human health risks and assessment of possible intervention options. Science of The Total Environment, Vol. 612, p. 148-169, 2018.

[27] ONODA, H.; HARUKI, M.; Influence of phosphate source on preparation of zinc phosphate white pigments. International Journal of Industrial Chemistry, Vol. 7, p. 309-314, 2016.

[28] DRAELOS, Z. D.; Colored facial cosmetics. Dermatologic Clinics, Vol. 18, p. $621-631,2000$.

[29] ANVISA, Agência Nacional de Vigilância Sanitária, Resolução de Diretoria Colegiada- RDC n³12, 10 de outubro de 2019. Available at: http://www.in.gov.br/en/web/dou/-/resolucao-rdc-n-312-de-10-de-outubro-de2019-222053954, Accessed at: 06/ 01/ 2021.

[30] ANVISA, Agência Nacional de Vigilância Sanitária, Resolução de Diretoria Colegiada- RDC n²37, 16 de julho de 2018. Available at: http://www.lex.com.br/legis_27683002_RESOLUCAO_RDC_N_237_DE_16_D E JULHO_DE_2018.aspx, Accessed at: 06/ 01/2021.

[31] ANVISA, Agência Nacional de Vigilância Sanitária, Resolução de Diretoria Colegiada- RDC n92, 9 de dezembro de 2008. Available at: http://bvsms.saude.gov.br/bvs/saudelegis/anvisa/2008/res0092_09_12_2008.html, Accessed at: 06/ 01/ 2021.

[32] ANVISA, Agência Nacional de Vigilância Sanitária, Resolução de Diretoria Colegiada- RDC nº176, 21 de setembro de 2006. Available at: https://www.in.gov.br/materia/lasset publisher/Kujrw0TZC2Mb/content/id/19300250/do1-2017-09-19resolucao-rdc-n-176-de-15-de-setembro-de-2017-19300004, Accessed at: 06/ 01/ 2021.

[33] ANVISA, Agência Nacional de Vigilância Sanitária, Resolução de Diretoria Colegiada- RDC n³32, 1 de dezembro de 2005. Available at: http://www.invitare.com.br/arq/legislacao/anvisa/RDC-332-de-2005-Disp-esobre-o-sistema-de-Cosmetovigil-ncia.pdf, Accessed at: 06/ 01/ 2021.
[34] ANVISA, Agência Nacional de Vigilância Sanitária, Resolução de Diretoria Colegiada- RDC n44, 9 de agosto de 2012. Available at: http://portal.anvisa.gov.br/documents/10181/3285555/RDC 44 2012_.pdf/a2489 836-8233-40bc-b880-c7719ae356fc, Accessed at: 04/ 07/ 2020.

[35] EU, 1976. Council Directive 76/768/EEC of 27 July 1976. Available at: https://eur-lex.europa.eu/eli/dir/1976/768/oj, Accessed at: 04/ 07/ 2020

[36] SAÇMACI, S.; SAÇMACI, M.; A new procedure for determination of nickel in some fake jewelry and cosmetics samples after dispersive liquid-liquid microextraction by FAAS. Applied Organometallic Chemistry, Vol. 31, p. e4081, 2017.

[37] BARROS, A. I.; SILVA, T. V.; FERREIRA, E. C.; GOMES NETO, J. A.; Determination of lead in eye shadow and blush by high-resolution continuum source graphite furnace atomic absorption spectrometry employing direct solid sampling. Journal of the Brazilian Chemical Society, Vol. 26, n. 1, p. 140-146, 2015.

[38] ARAÚJO, A. A. S; MERCURI, L. P.; SEIXAS, S. R. S.; STORPIRTIS, S.; MATOS, J. R.; Determinação dos teores de umidade e cinzas de amostras comerciais de guaraná utilizando métodos convencionais e análise térmica. Revista Brasileira de Ciências Farmacêuticas, Vol. 42, n. 2, p. 260-277, 2006.

[39] ATZ, V. L.; POZEBON, D.; Graphite furnace atomic absorption spectrometry (GFAAS) methodology for trace element determination in eye shadow and lipstick. Atomic Spectroscopy, Vol. 30, p. 82-91, 2009.

[40] MITSUI T., New Cosmetic Science. Elsevier Science 1997.

[41] ANVISA, Agência Nacional de Vigilância Sanitária, Resolução de Diretoria Colegiada- RDC nº15, 24 de abril de 2015. Available at: http://bvsms.saude.gov.br/bvs/saudelegis/anvisa/2015/rdc0015_24_04_2015.pdf Accessed at: 06/ 01/ 2021.

TECNO-LÓGICA, Santa Cruz do Sul, v. 25, n. 1, p. 59-72, jul./dez. $2021^{\text {A }}$ 